\title{
Sosialisasi Keselamatan Di Laut Bagi Masyarakat Pulau Balang Lompo
}

\author{
Hasdinar Umar ${ }^{1 *}$, Daeng Paroka ${ }^{1}$, Achmad Yasir Baeda ${ }^{1}$, Chairul Paotonan ${ }^{1}$, Sabaruddin \\ Rahmanr $^{1}$ \\ Departemen Teknik Kelautan, Fakultas Teknik, Universitas Hasanuddin ${ }^{1}$ \\ hasdinar.umar@gmail.com ${ }^{1 *}$
}

\begin{abstract}
Abstrak
Angkutan pelayaran rakyat merupakan sarana vital bagi masyarakat yang ada di pulau-pulau kecil, seperti Balang Lompo. Sarana tersebut berfungsi sebagai alat angkut barang maupun penumpang. Kurangnya pemahaman operator maupun pengguna sarana tersebut menjadi salah satu faktor penyebab terjadinya kecelakaan di laut.

Kegiatan ini bertujuan meningkatkan pemahaman masyarakat pulau Balang Lompo terkait pentingnya pemahaman keselamatan di laut saat menggunakan sarana kapal pelayaran rakyat. Kegiatan pengabdian ini dilakukan dengan metode survey kuesioner kepada 57 responded di Pulau Balang Lompo dan pembagian Leaflet petunjuk penggunaan alat keselamatan yang dibuat lebih menarik untuk memberikan penjelasan kepada responden sebagai pengguna sarana transportasi laut. Keberhasilan program dievaluasi menggunakan keuseioner yang disebar sebelum dan setelah diadakannya sosialisasi keselamatan di atas kapal.

Setelah pelaksanaan sosialisasi terjadi peningkatan nilai rata-rata pemahaman masyarakat terhadap aspek keselamatan sebelum sosialisasi dari 3,6 menjadi 4,1, selain itu responden pada umumnya telah memahami dengan baik bahwa jika terjadi kecelakaan di laut maka akses keluar dari kapal bukan hanya dari pintu tapi juga bisa melalui jendela kapal yang dibuat lebih luas.

Kata Kunci: Angkutan Pelayaran; Keselamatan Laut; Pemeliharaan; Pengenalan Keselamatan; Prosedur Keselamatan.

Abstract

Public sea transportation is a vital means for people living on small islands, such as Balang Lompo. This facility functions as sea transportation tools, for both goods and passengers. Lack of operators and users understanding of these facilities, is one of the factors causing accidents at sea. The aim of this activity is to increase Balang Lompo community understanding, due to the importance of the safety at sea when they are using a ship as a public transportation facility. This activity was carried out using a questionnaire survey to 57 respondent which also residents of Balang Lompo Island; with an atractive activity also carried out at the distribution of safety equipment instructions to respondent due to their activity as users of public transportation facility. The successfulness of the program then evaluated by using a questionnaire distributed before and after the socialization of on-board safety. After the socialization, there was an increase of 3.6 to 4.1 points in the average value of the public understanding of the safety aspects before the socialization; besides that, the respondents generally understood well that if an accident at sea occurs, they can use not only the door but also sidescuttles that have been made wider, to exit the ship calmly and in safely manner.
\end{abstract}

Keywords: Sea Transportation; Marine Safety; Maintenance; Safety Introduction; Safety Procedures.

\section{Pendahuluan}

Angkutan pelayaran rakyat merupakan sarana vital bagi masyarakat yang ada di pulau-pulau kecil. Sarana tersebut berfungsi sebagai alat angkut barang maupun penumpang. Kurangnya pemahaman operator maupun pengguna sarana tersebut menjadi salah satu faktor penyebab terjadinya kecelakaan di laut (Gambar 1) dimana penumpang berkumpul di geladak atas (top deck) dapat mengakibatkan perahu tidak stabil. Selain penumpang, operator pun harus sadar dan tegas mengambil sikap terkait bahaya tersebut. Namun terkadang pula kru kapal meletakkan barang muatan di geladak atas. Belum lagi ketersediaan alat-alat keselamatan yang tidak sesuai 
standar, seperti baju pelampung, alat pemadam kebakaran. Selain itu sistem perlengkapan dan konstruksi kapal yang tidak sesuai standar keselamatan sering ditemukan di lapangan.

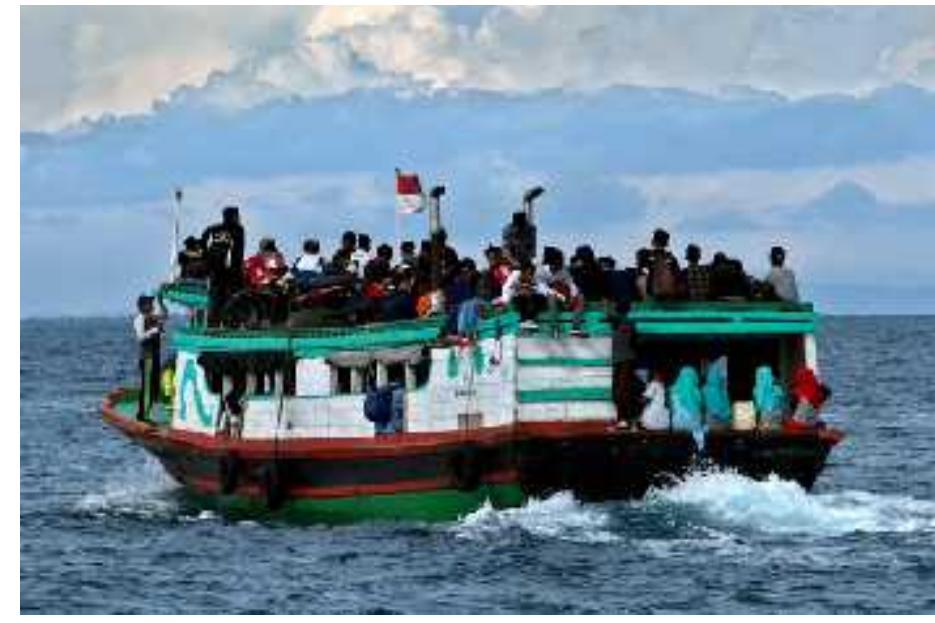

Gambar 1. Kondisi muatan angkutan pelayaran rakyat (Media Indonesia, 2018)

Selain faktor di atas, penggunaan kapal yang tidak sesuai fungsinya dapat membahayakan keselamatan pelayaran. Misalnya penggunaan kapal penangkap ikan untuk mengangkut penumpang sehingga terjadi kecelakaan KM Arista yang menewaskan 15 orang pada tahun 2018 (BBC News Indonesia, 2018) dan karamnya KM Lestari Maju di perairan Selayar pada tahun 2018 (KNKT, 2018).

Di samping kondisi keselamatan, kondisi sanitasi di atas kapal juga perlu menjadi perhatian penting. Kapal penumpang merupakan alat angkutan umum baik yang bersifat nasional maupun internasional, dimana bila keadaan sanitasinya kurang memenuhi syarat kesehatan, maka dapat menjadi sumber penularan penyakit sehingga perlu mendapat pengawasan dalam hal sanitasinya (Erlani dan Nardilla, T., (2018).

\section{Latar Belakang Teori}

Kapal-kapal berbendera Indonesia yang selama ini tidak termasuk dalam aturan internasional seperti SOLAS (Safety of Life at Sea), Standard Training Certificate and Watchkeeping (STCW), International Safety Management (ISM) Code, Marine Pollution (Marpol) kini wajib menggunakan Standar Kapal Non Konvensi (SKNK), menyusul terbitnya Surat Keputusan Jenderal Perhubungan Laut No. Um. 008/9/20/DJPL-12 tentang Pemberlakuan Standard an Petunjuk Teknis Pelaksanaan Kapal Non Konvensi Berbendera Indonesia pada 16 Februari 2012. Menurut Standar tersebut, kapal-kapal kayu atau kapal layar motor (KLM) dengan mesin penggerak masuk sebagai kategori kapal non konvensi.

Menurut Eka (2019) menyebutkan bahwa keselamatan pelayaran adalah segala hal yang ada dan dapat dikembangkan dalam kaitannya dengan tindakan pencegahan kecelakaan pada saat melaksanakan kerja di bidang pelayaran. Dalam UU No. 17 Tahun 2008 tentang Pelayaran, Pasal 1 butir 33 menyatakan bahwa keselamatan dan keamanan pelayaran adalah suatu keadaan terpenuhinya persyaratan keselamatan dan keamanan yang menyangkut angkutan di perairan, kepelabuhan, dan lingkungan maritim. Pasal 1 butir 33 menyatakan bahwa kelaiklautan kapal adalah keadaan kapal memenuhi persyaratan keselamatan kapal, pencegahan pencemaran 
perairan dari kapal, pengawakan, garis muat, pemuatan, kesejahteraan awak kapal dan kesehatan penumpang, status hukum kapal, manajemen keselamatan dan pencegahan pencemaran dari kapal, dan manajemen keamanan kapal untuk berlayar di perairan tertentu.

Kapal roro digolongkan pada kapal tipe pelayaran pantai (short international voyage) karena jarak kurang dari 200 mil laut. Dengan demikian, peralatan yang dipersyaratkan dalam SOLAS sebagai minimum alat keselamatan yang harus dimiliki oleh sebuah kapal adalah life buoy, life jacket, inflatable life raft, sekoci penyelamatn (lifeboat), alat pelontar tali, pakaian cebur. Setiap pemilik bersama awak kapal diharuskan merawat peralatan keselamatan kapal. Berdasarkan Peraturan Pemerintah Republik Indonesia nomor 51 tahun 2002 tentang perkapalan pada pasal 71, (1) alat penolong di kapal harus dipelihara dan dirawat sesuai dengan persyaratan; (2) pemeliharaan dan perawatan jenis alat penolong tertentu yang memerlukan pemeliharaan dan perawatan di darat, harus dilakukan pada bengkel pemeliharaan dan perawatan yang diakui.

Berdasarkan peraturan menteri perhubungan nomor PM 39 tahun 2015 diatur terkait standar pelayanan penumpang angkutan penyeberangan di kapal diantaranya informasi penempatan dan tata cara penggunaan peralatan keselamatan saat sebelum kapal berangkat yang ditayangkan dalam bentuk visual dan/atau audio. Selain itu, penumpang harus mendapat penjelasan terkait dengan tindakan yang harus dilakukan saat terjadi keadaan darurat.

Beberapa peralatan keselamatan (Gambar 2) yang harus diinformasikan kepada penumpang adalah penempatan dan cara penggunaan lifejackets, lifebuoy, alat pemadam kebakaran, tempat berkumpul (muster station) dan penunjuk arah evakuasi menuju muster station.

1. Muster station, merupakan titik yang digunakan sebagai tempat berkumpul saat terjadi kecelakaan. Penumpang berkumpul di titik tersebut untuk selanjutnya dievakuasi turun dari kapal. 


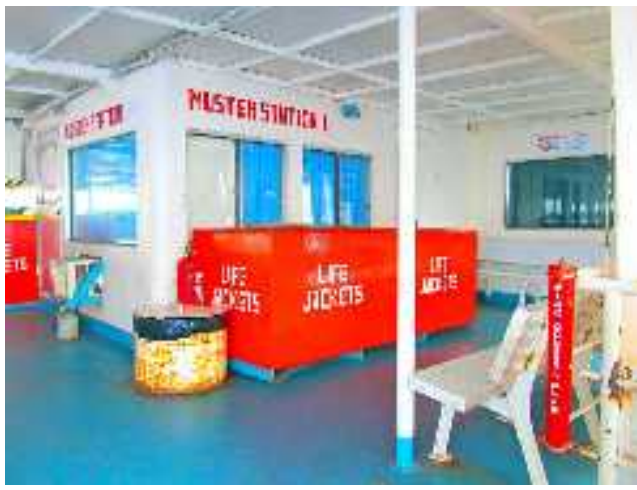

Muster station

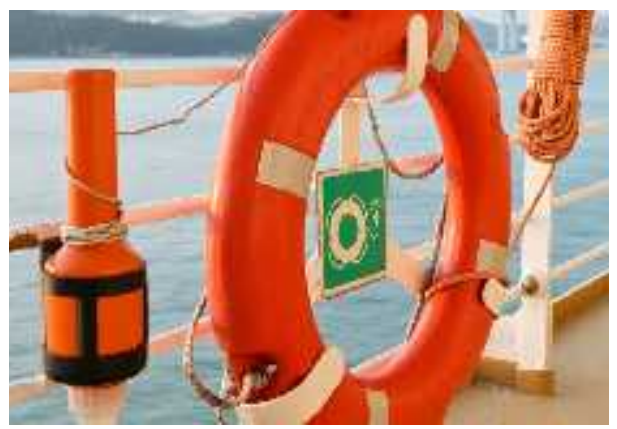

Life buoy

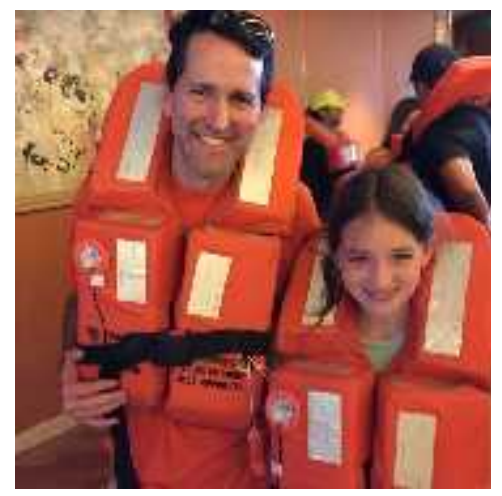

Life jacket

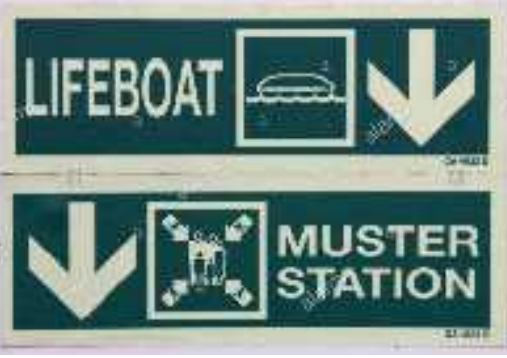

Petunjuk arah

Gambar 2. Peralatan Keselamatan (DNVGL, 2016)

2. Safety and fire control plan. Pemilik kapal menyampaikan dokumen tersebut untuk dilakukan pemeriksaan dan pengesahan dan selanjutnya dipasang di kapal sebagai acuan dalam pemeriksaan perlengkapan keselamatan dan alat pemadam di atas kapal.

3. Safety drill. Pelaksanaan latihan keselamatan khususnya pada kapal penumpang terutama pelatihan orang meninggalkan kapal (abandon ship), sangat diwajibkan dilakukan oleh awak kapal. Selain meningkatkan kemampuan awak kapal dalam menangani kondisi darurat, sisi penumpang perlu juga untuk diberikan pemahaman secara benar tentang tindakan yang dilakukan ketika terjadi kondisi darurat.

4. Life saving plan. Gambar tersebut terlebih dahulu harus diperiksa dan disetujui oleh Direktorat Perkapalan dan Kepelautan. Pada gambar tersebut dapat memberikan informasi yang dapat digunakan dalam penentuan alat-alat keselamatan yang harus berada di atas kapal.

\section{Metode Pelaksanaan}

Survey dilakukan untuk mengetahui kondisi alat keselamatan di atas kapal, tanda-tanda petunjuk dan larangan serta aktifitas penumpang yang dapat mengganggu keselamatan pelayaran.

Media sosialisasi dibuat untuk dua kelompok masyarakat yang dituju, yaitu siswa sekolah dan orang tua siswa. Sehingga untuk keperluan tersebut disiapkan dua jenis media sosialisasi yaitu video dan brosur. Adapun informasi yang akan dimuat dalam kedua media tersebut adalah:

1. Selama pelayaran, semua penumpang berada di geladak penumpang. 
2. Petunjuk cara penggunaan alat keselamatan: life jacket dan life buoy.

3. Petunjuk cara penggunaan alat pemadam kebakaran.

4. Petunjuk cara menemukan jalan keluar dan tindakan yang harus dilakukan menuju pintu keluar saat terjadi keadaan darurat.

5. Petunjuk tindakan yang harus dilakukan saat akan meninggalkan kapal dalam kondisi keadaan darurat, tindakan selama berada di air.

6. Petunjuk tindakan yang boleh/tidak boleh dilakukan selama berada di atas kapal, diantaranya: merokok di tempat yang telah disediakan, tidak duduk atau berdiri di tempat yang berbahaya.

Kuesioner dibuat untuk memperoleh beberapa informasi terkait pemahaman masyarakat pada:

1. Cara menggunakan peralatan keselamatan seperti life jacket, life buoy dan alat pemadam kebakaran.

2. Cara meninggalkan kapal saat terjadi keadaan darurat.

3. Hal-hal yang boleh/tidak boleh dilakukan selama berada di atas kapal.

Selain itu, kuesioner juga dibuat untuk memperoleh informasi dari awak kapal diantaranya:

1. Pelatihan yang pernah diikuti terkait penanganan penumpang saat terjadi keadaan darurat di atas kapal.

2. Jadwal pengecekan, perbaikan dan penggantian alat keselamatan di atas kapal.

Pengisian kuesioner dilakukan untuk mengevaluasi keberhasilan sosialisasi. Pengisian kuesioner dilakukan dua kali, pengisian pertama sebelum pelaksanaan sosialisasi, pengisian kedua setelah dilakukan sosialisasi.

Sosialisasi keselamatan di laut dilakukan dengan melakukan edukasi kepada siswa sekolah yang ada di pulau Balang Lompo. Pada kegiatan tersebut juga akan dilaksanakan pembagian media sosialisasi berupa brosur.

\section{Hasil dan Diskusi}

\subsection{Kondisi Umum Kapal Angkutan Penumpang antar Pulau}

Pelaksanaan survey dilakukan di pulau Balang Lompo dengan melakukan wawancara terhadap lima puluh tujuh orang responden (Gambar 3). 


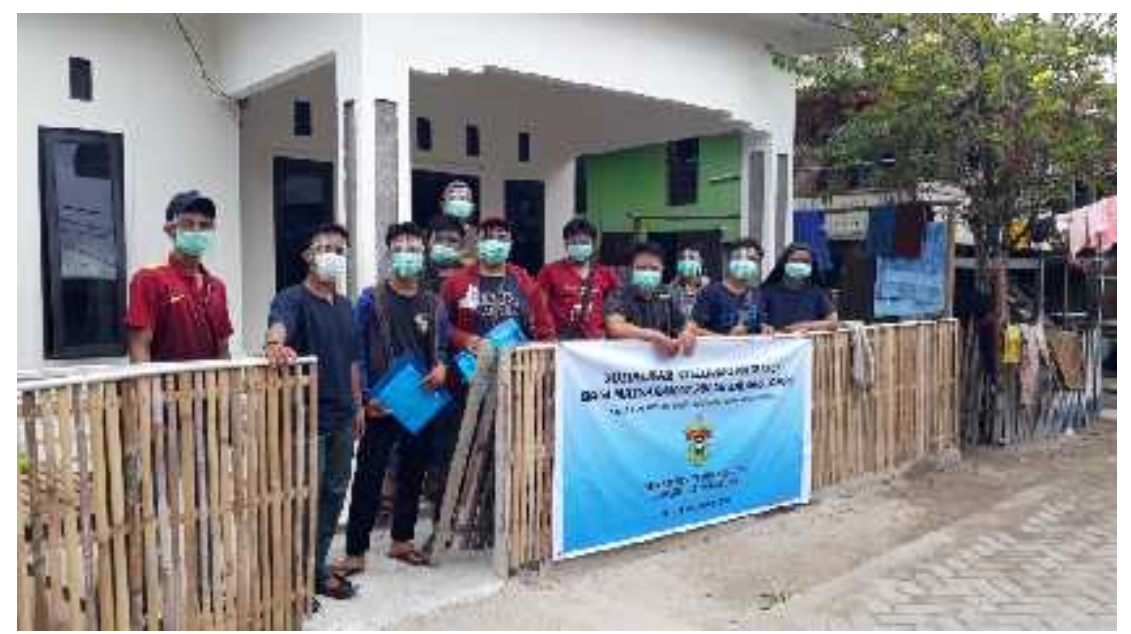

Gambar 3. Tim survey foto bersama sebelum pelaksanaan sosialisasi

Berdasarkan pengamatan di lapangan, umumnya kapal angkutan penumpang antar pulau yang ada di pulau Balang Lompo masih memiliki beberapa kekurangan terkait aspek kenyamanan dan keselamatan, diantaranya:

1. Geladak penumpang dan geladak atas yang sangat rendah, sekitar $80 \mathrm{~cm}$, mengakibatkan penumpang kurang leluasa bergerak.

2. Penempatan muatan di geladak atas tidak baik pada aspek stabilitas kapal, terutama pada saat kondisi cuaca buruk.

Gambar 4 berikut menunjukkan kondisi kapal penumpang di pulau Balang Lompo dimana luas jendela yang kecil tidak dapat dilalui oleh penumpang keluar di saat terjadi kecelakaan di laut. Selain itu, jarak antara geladak penumpang dan geladak atas yang rendah, sekitar $80 \mathrm{~cm}$, mengakibatkan penumpang tidak leluasa bergerak.

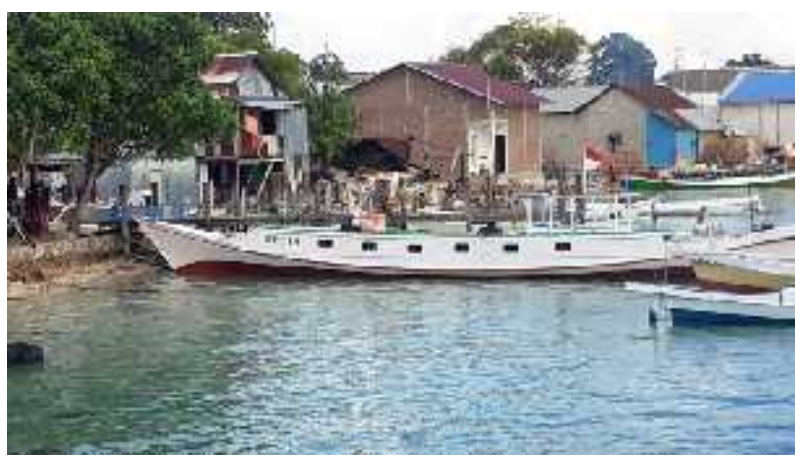

a. Typikal kapal penumpang

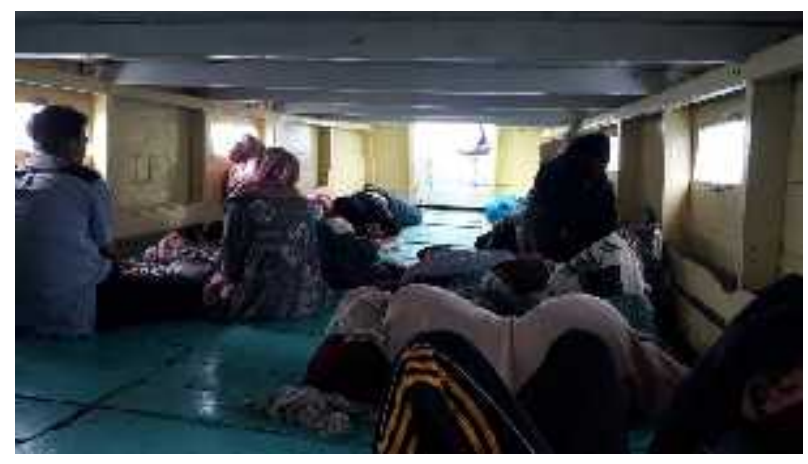

b. Situasi di geladak penumpang

Gambar 4. Kondisi kapal penumpang di pulau Balang Lompo 


\subsection{Karakteristik responden}

Tim survey menyebarkan kuesioner ke penduduk sebanyak 57 orang dengan usia yang beragam mulai di bawah 20 tahun sampai di atas 60 tahun, responden terbanyak berdasarkan usia adalah 30 - 35 tahun. Berdasarkan tingkat pendidikan, responden yang ditemui sebanyak 46,15 persen tingkat pendidikan sekolah dasar. Adapun jenis pekerjaan, sebanyak 50 persen berprofesi sebagai nelayan. Sebanyak 61,4 persen dari responden menggunakan angkutan penumpang antar pulau sebanyak tiga kali dalam sebulan. Dari 57 responden yang ada, 6 orang diantaranya tidak berdomisili di pulau Balanglompo. Mereka ke pulau Balanglompo dalam rangka mengunjungi keluarga maupun urusan lainnya.

\subsection{Pemahaman masyarakat terhadap keselamatan di atas kapal}

Secara umum, penumpang telah mengetahui cara penggunaan baju dan pelampung penolong. Dalam pengeditan video, ditampilkan hal-hal penting yang harus dilakukan penumpang saat berada di atas kapal, diantaranya:

1. Selama pelayaran, semua penumpang berada di geladak penumpang dan kendaraan dimatikan.

2. Petunjuk cara penggunaan alat keselamatan: life jacket dan life buoy.

3. Petunjuk cara penggunaan alat pemadam kebakaran.

4. Petunjuk cara menemukan muster point dan tindakan yang harus dilakukan menuju muster point saat terjadi keadaan darurat.

5. Petunjuk tindakan-tindakan yang boleh/tidak boleh dilakukan selama berada di atas kapal, diantaranya: merokok di tempat yang telah disediakan, tidak duduk atau berdiri di tempat yang berbahaya.

\subsection{Pengisian kuesioner}

Khusus pada penumpang, pengisian kuesioner dilakukan dua kali, pengisian pertama dilakukan sebelum pelaksanaan sosialisasi, pengisian kedua setelah dilakukan sosialisasi (Gambar 5). Pada pengisian pertama, tingkat pengetahuan masyarakat terkait pentingnya menggunakan jaket penolong sudah sangat baik dengan nilai rata-rata 4 dari skala nilai 5. Diikuti dengan pemahaman masyarakat untuk penggunaan jaket penolong (aspek no. 6) pada nilai rata-rata 3,7. Selanjutnya nilai pemahaman masyarakat pada aspek no. 1, 2 dan 4 berada pada nilai rata-rata 3,5.
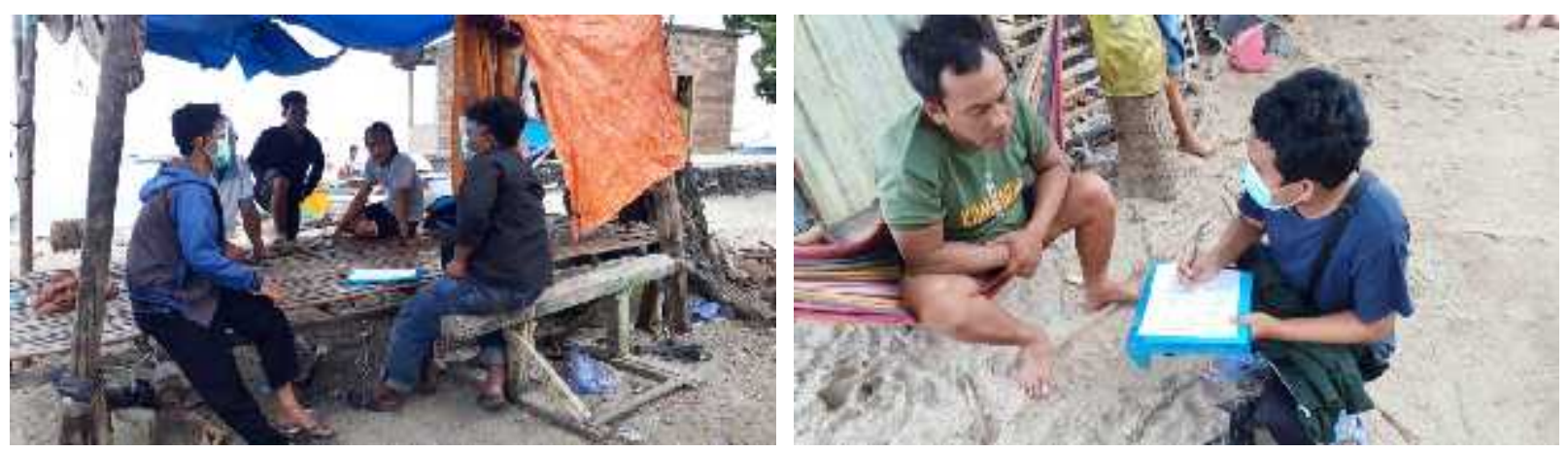

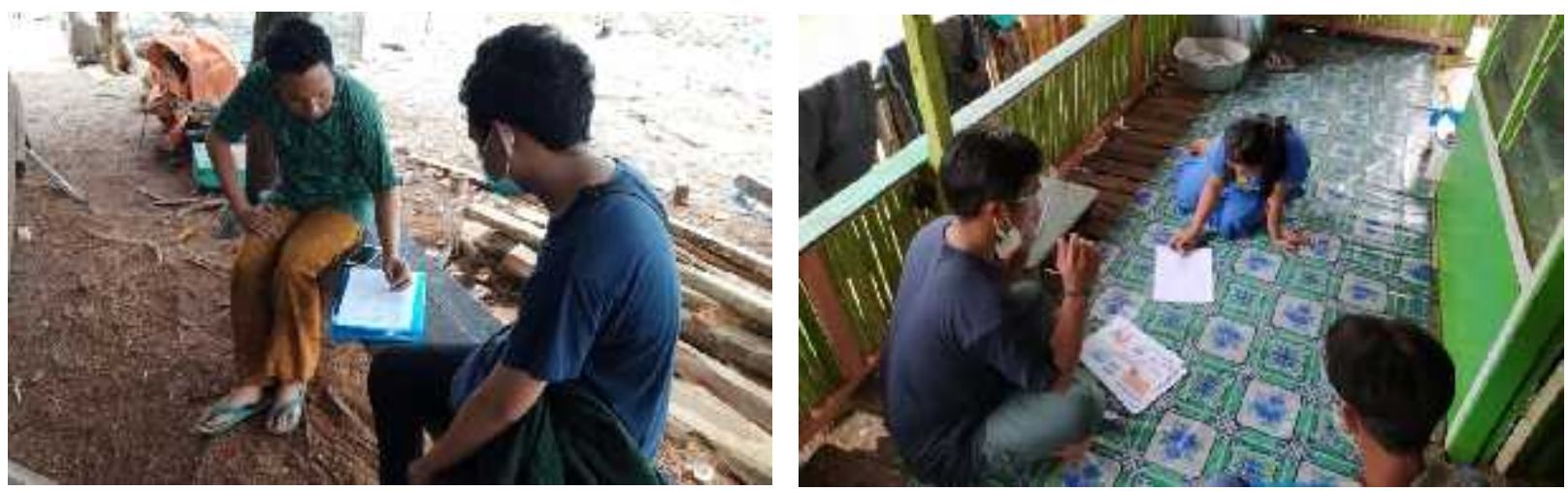

Gambar 5. Pengisian kuesioner

\subsection{Sosialisasi keselamatan penumpang}

Sosialisasi keselamatan penumpang (Gambar 6) dilakukan dengan memberikan leaflet terkait aspek keselematan di atas kapal setelah pengisian kuesioner pertama seperti yang diuraikan di sub bab sebelumnya.
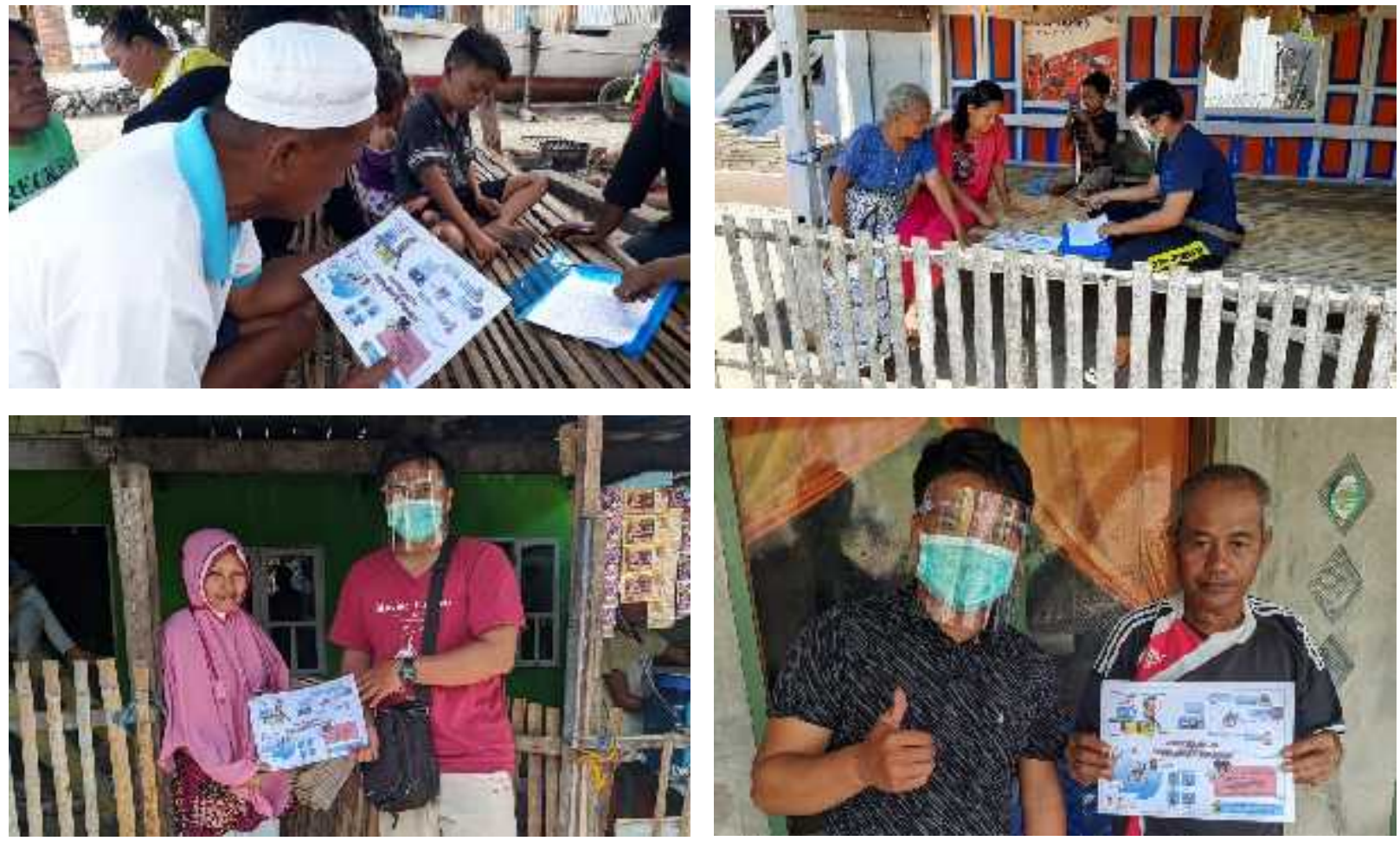

Gambar 6. Pemberian materi sosialisasi

Terjadi peningkatan nilai rata-rata pemahaman masyarakat terhadap aspek keselamatan sebelum sosialisasi sebesar 3,6 menjadi 4,1 setelah dilaksanakan sosialisasi. Pemahaman pada aspek no. 1 dan no. 7 mengalami perubahan tertinggi dimana terjadi penambahan nilai pemahaman sebesar 0,7 . Setelah pelaksanaan sosialisasi, responden lebih memahami lagi bahwa duduk di geladak atas berbahaya bagi keselamatan pelayaran terutama pada saat kondisi cuaca buruk. 
Peningkatan tingkat pemahaman selanjutnya diikuti pada aspek no. 2 dengan penambahan nilai pemahaman sebesar 0,6. Setelah pelaksanaan sosialisasi, responden pada umumnya telah memahami dengan baik bahwa jika terjadi kecelakaan di laut, maka akses keluar dari kapal selain melewati pintu masuk, juga dapat melalui jendela dengan catatan jendela yang ada saat ini dibuat lebih luas agar mudah dilalui orang.

\section{Kesimpulan}

Kegiatan pengabdian masyarakat dilaksanakan di Pulau Balang Lompo untuk memberi pemahaman tentang alat keselamatan di laut. Berdasarkan hasil survey, setelah pelaksanaan sosialisasi terjadi peningkatan nilai rata-rata pemahaman masyarakat terhadap aspek keselamatan sebelum sosialisasi sebesar 3,6 menjadi 4,1, selain itu responden pada umumnya telah memahami dengan baik bahwa jika terjadi kecelakaan di laut maka akses keluar dari kapal bukan hanya dari pintu tapi juga bisa melalui jendela kapal yang dibuat lebih luas.

\section{Ucapan Terima kasih}

Kegiatan ini terlaksana atas dukungan dana dari Fakultas Teknik Universitas Hasanuddin melalui Laboratory Based Education skim pengabdian kepada masyarakat. Penulis menyampaikan terima kasih kepada Kepala Desa Pulau Balang Lompo atas izin pelaksanaan kegiatan dan penduduk pulau Balang Lompo atas kerja samanya yang baik selama pelaksanaan survey.

\section{Daftar Pustaka}

BBC News Indonesia, (2018). Sudah Lima Belas Orang Tewas Akibat Kapal Karam Karena Kelebihan Beban, BBC News Indonesia, Juni 2018.

Media Indonesia, (2018). Kapal Pelayaran Rakyat Tingkatkan Koneksi Antarpulau, Media Indonesia, April 2018.

KNKT, (2018). Laporan Investigasi Kecelakaan Pelayaran, Miringnya Kapal Lestari. Maju (IMO 8720541) di Perairan Pabadilang Kepulauan Selayar, Sulawesi Selatan Republik Indonesia.

Erlani dan Nardilla, T., (2018). Kondisi sanitasi kapal penumpang ferry di wilayah kerja pelabuhan Bira kec. Bonto Bahari kab. Bulukumba. Jurnal Sulolipu, Vol. 18 No. I, h. 9-14.

Eka P. W., (2019). Analisis Pengaruh Faktor Pemanduan, Sarana Bantu Navigasi Pelayaran, Stasiun Radio Pantai Dan Kompetensi Terhadap Keselamatan Pelayaran (Studi Pada Pelabuhan Tanjung Emas Semarang). Repository Universitas Maritim AMNI, Semarang. Januari 2020.

DNVGL, (2016). Class Guideline - Maintenance of safety equipment. 